\title{
Diş aşınmalarının etyolojisi, prevalansı ve patogenezi
}

\section{The etiology, prevalence and pathogenesis of tooth wear}

\author{
Özge TÜRKOĞLU1', Ali Can BULUT²
}

${ }^{1}$ Kırıkkale Ağız Diş Sağlığı Merkezi, Kırıkkale/Türkiye

${ }^{2}$ Kırıkkale Üniversitesi Diş Hekimliği Fakültesi, Protetik Diş Tedavisi Anabilim Dalı, Kırıkkale/Türkiye

\section{Öz}

Diş ve diş sert doku kayıplarının en yaygın nedeni diş çürüğüdür. Florür uygulamalarıyla birlikte diş çürüğünün şiddeti, prevelansı ve insidansı azalmakta, dişlerin ağızda kaldığı süre uzamaktadır. Dişılerin ağızda kalma süresini etkileyen bir diğer faktör de diş aşınmalarıdır. Diş aşınmaları çürük içermeyen, geri dönüşümsüz, yıkıcı ilerleyen diş sert doku kaybıdır. Diş aşınmaları abrazyon, atrizyon, erozyon ve abfraksiyon sonucu oluşmaktadır. Bu derlemede diş aşınmalarının etyolojisi, prevalansı ve patagenezi incelenmiştir.

Anahtar Kelimeler: Diş aşınmaları, abrazyon, atrizyon, erozyon, abfraksiyon

\section{ABSTRACT}

The most common reason for tooth and dental hard tissue loss has been dental caries. Since application of fluoride, the prevalence, incidence and severity of caries has declined and the dental life expectancy has increased. One of the most common factor associated with this prolonged dental life expectancy is tooth wear. Tooth wear is an irreversible, non carious, destructive process, which results in a functional loss of dental hard tissue. It can manifest as abrasion, attrition, abfraction and erosion. This article will describe the etiology, prevalance and pathogenesis of tooth wear.

Keywords: Tooth wear, abrasion, attrition, erosion, abfraction 


\section{Diş Aşınmaları}

Günümüzde yaşam süresinin uzaması ve dişlerin daha uzun süre ağızda kalmasına bağlı olarak diş çürüklerinden sonra ağız boşluğunun en sık görülen patolojileri diş aşınmalarıdır. Diş aşınmaları; çürük, travma ve gelişimsel bozukluk olmadan görülen diş dokularının kaybı olarak tanımlanmaktadır [1-3]. [Şekil 1]

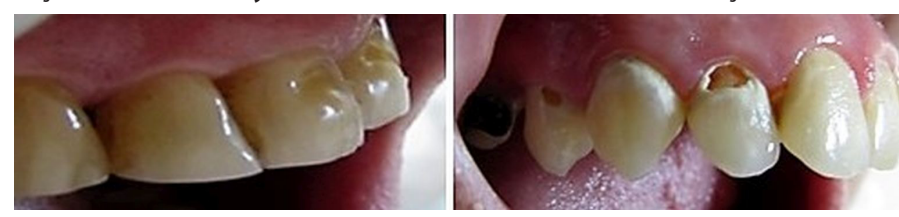

Resim 1: Servikal bölgede oluşanmikroorganizmaların eşlik ettiği kole çürüğü ve diş aşınması sonucu oluşan çürüksüz servikal lezyonun klinik görünümleri

Çalışmalarda diş aşınmalarının görülme sıklığının \%5-85 aralığında olduğu gösterilmiştir [4].

Van ve ark.'ları şiddetli diş aşınmalarının 20 yaş grubunda \%3, 70 yaş grubunda \%17 oranında olduğunu ve aşınmanın şiddetinin ve prevalansının yaşla birlikte arttığını bildirmişlerdir [5]. Eligüzeloğlu ve ark.'ları çalışmalarında her 5 kişiden birinde servikal bölgede oluşmuş diş aşınma lezyonun bulunduğunu bildirmişlerdir [6].

Diş aşınmalarının görülme sıklığının maksillada molar dişlerde $\% 84.9$, premolarlarda \% 68.9, kaninlerde \%74.1, kesici dişlerde $\% 97$; mandibulada ise sırasıyla \%85.2, \%59.3, \%78.6 ve \%97.4 olduğu; diş aşınmalarının diğer bölgelere kıyasla oklüzal, insizal ve servikal bölgede daha sık gözlendiği bildirilmiştir [7].

Literatürde bazı çalışmalarda cinsiyetin, diş aşınmalarının oluşumunda etken olmadığı bildirilirken; erkeklerde, kadınlardan daha sık diş aşınması oluştuğunu bildiren çalışmalarda bulunmaktadır [8,9].

Dişaşınmalarıetiyolojidekiçeşitliliğebağlıolarakerozyon,atrizyon, abrazyon, abfraksiyon başlığı altında değerlendirilmektedir [10]. $\mathrm{Bu}$ terimler oluşan diş aşınma süreçlerinin birbirinden farklı etkenlerle oluştuğunu göstermektedir [11].

\section{Atrizyon}

Atrizyon, Latince'de bir şeyi sürterek aşındırma anlamına gelen 'Attrium' kelimesinden türemiştir. Dental atrizyon ise yabancı cisimlerden kaynaklanmayan oklüzal ve aproksimal yüzeylerde mekanik bir etken olmaksızın, dişin dişe teması sonucu oluşan diş sert doku kaybı olarak tanımlanır. Atrizyonda iki yüzeyin doğrudan temasıyla oluştuğu genel kabul görse de, iki yüzey arasında aşınmış mine partiküllerinin bulunması nedeniyle atrizyona abraziv etkilerinde eşlik ettiği düşünülmektedir [12]. Çiğneme sırasında besinlerin neden olduğu abraziv aşınma 'Demastikasyon' olarak da tanımlamaktadır [13].

Atrizyon, fizyolojik ve patolojik olarak değerlendirilebilir. Yaşla birlikte artan, normal çiğneme fonksiyonuyla yavaş ve sürekli olarak gelişen, fizyolojik sürece bağlı olarak oluşan dişlerin oklüzal yüzeyindeki aşınmalar, fizyolojik atrizyon olarak değerlendirilir. Patolojik atrizyondan ise; kişinin yaşına göre erken oluşmuş ve oklüzal yüzeyde normalden fazla miktarda diş sert dokusu kaybının gözlendiği durumlarda söz edilebilir. Diş sıkma ve gıcırdatma gibi alışkanlıklar, oklüzal bozukluklar, prematür kontaklar patolojik atrizyona neden olmaktadır. Atrizyon lezyonları başlangıçta küçük, cilalı gibi görünen, düz faset yüzeyi şeklindedir ve antogonist dişte de benzer bir lezyon oluşmuştur. Patolojik ve fizyolojik atrizyon genelde maksillar dişlerin oklüzal, insizal ve palatinalinde; mandibular dişlerin labial yüzlerinde oluşur [14,15].

\section{Abrazyon}

Abrazyon, Latince'de kazımak anlamına gelen 'Abrasum' kelimesinden türemiştir. Dental abrazyon, yabancı cisimlerin ve/veya alışkanlıkların mekanik etkilerle dişler üzerinde oluşturduğu patolojik sert doku kayıplarıdır [12].

Etyolojisiniyanlışalışkanlıklar, mesleki alışkanlıklar-zorunluluklar ve yanlış ağız bakımı oluşturur. Mesleki zorunluluklar arasında müzik aleti çalarken ağızlığın sürekli dişler arasında tutulması sayılabilir. Marangoz ve terzilerin ağızda sürekli çivi ve iğne tutması sonucu gelişen lezyonlar mesleki alışkanlığa bağlı oluşur. Yanlış alışkanlıklar arasında tırnak yeme, çekirdek çitleme ve pipo içme alışkanlığı sayılabilir $[3,16]$.

Aşırı güçlü ve sık diş fırçalama alışkanlığına bağlı olarak da dişlerin servikal bölgelerinde abrazyon defektleri gözlenebilir. Fırça abrazyonu olarak isimlendirilen bu lezyonlar firça kıllarının tasarımından, sertliğinden, sıklığından, yapısından ve kullanılan diş macununun abraziv özelliğinden etkilenmektedir. Yanlış diş ipi kullanmak ve dişlerin arasına kürdan sokma alışkanlığının sonucu olarak dişlerin ara yüzlerinde abfraksiyon defekti oluşabilmektedir $[3,16,17]$.

Zafersoy ve ark.'ları çalışmalarında servikal bölgede oluşan diş aşınmalarında abrazyon etkeninin oranını \%55.05, erozyon etkeni oranını\%27.27 olarak bildirmiştir [9].

\section{Abfraksiyon}

Abfraksiyon, Latince'de kırılmak anlamına gelen 'Fractio' kelimesinden türemiştir $[18,19,20]$. Abfraksiyon ilk defa 1991'de Grippo tarafından dişlerde oluşan eğilme (fleksural esneme) sonucu mine-sement birleşimindeki mine rodlarında kırılma ve madde kaybı olarak tanımlanmıştır [20].

Genel görüş, dişe aksı dışında uygulanan karmaşık, esnek, çekme ve basma kuvvetlerinin mine-sement sınırında mikro çatlaklar oluşturması ve dişin servikal bölgesinden kırılarak kopması sonucu keskin kenarlı sert doku kayıpları meydana gelmesi şeklindedir [16,21].

Abfraksiyon oluşumunda bruksizmin primer etken olabileceği 
90'Iı yılların başında Grippo tarafından bildirilmiştir [20]. Ancak son klinik çalışmalarda abfraksiyon lezyonu bulanan hastaların tamamında bruksizmin gözlenmemesi gerekçesiyle, oklüzal yükleme ile abfraksyon oluşumu arasındaki pozitif ilişkiyi doğrulanmamaktadır [22,23].

Yapılan son çalışmalarda abfraksiyon oluşumunun multifaktoriyal olduğu, bruksizm ve prematür kontak gibi oklüzal faktörler ile abfraksiyon lezyonları arasında zayıf ilişki bulunduğu ancak oluşmuş lezyonun ilerlemesine katkı sağladığı bildirilmektedir. Günümüzde abfraksiyon teorisi halen kesinlik kazanmamıştır [23,24,25]

Bu lezyonlar genellikle dişlerin bukkal yüzeyinde mine-sement birleşimde gözlenir ve prevelansı \%27-85 arasındadır [26]. Abfraksiyon lezyonları kama defekti olarak da isimlendirilirken tipik olarak irregüler 'V' veya kama şeklinde oluşmaktadır. Lezyonların şekli oklüzal kuvvetlere bağlı olarak oluşan, basma ve çekme alanlarına göre değişmektedir [27]. Abfraksiyon lezyonları tek başına görülebildiği gibi, abraziv etkiler ya da eroziv etkilerle birlikte de görülebilmektedir [13].

\section{Erozyon}

Erozyon, Latince'de çürümek anlamından gelen 'Erodore, Erosi, Erosum' kelimelerinden türetilmiştir. Erozyon bir maddenin yüzeyinin kademeli olarak yıkılmasıdır. Dental erozyon bakteri içermeyen kimyasal etkene bağlı olarak oluşan diş sert doku kaybıdır [28]. Erozyon prevalansının okul öncesi çocuklarda \%6-50; adolesanlarda \%11-100; yetişkinlerde \%4-82 olduğu bildirilmiştir [29,30].

Modern hayattan post modern hayata geçişte artan hayat temposu, diyet alışkanlıklarının değişmesi ve asitli içecek tüketiminin artmasıyla, özellikle çocuk yaşlar denebilecek dönemde dahil olmak üzere, toplumlarda dental erozyon görülme sıklığı ve şiddeti giderek artmaktadır. Çocuklarla yapılan uzun dönemli çalışmalar da, erozyon insidansının adolesanlarda \%12.3-\%26.5 olduğunu bildirilmiştir [31,32].

\subsection{Erozyonun Patogenezi}

Dental erozyon mikroskobik olarak yüzeysel tabakanın yumuşaması ve ardından mine yüzeyinin tamamen çözünerek ortadan kalkmasıyla oluşan iki basamaklı bir süreçtir. İlk basamak diş yüzeyine oranla daha az doymuş çözeltilerin, dental pelikıla diffüzyonu ile başlar. Diş yüzeyindeki sıvı ortamda biriken asidik iyonlar, mine dokusunda, yüzeyden birkaç mikrometre derinliğinde mineral kaybına sebep olur. Bu tabakaya yumuşama tabakası adı verilmektedir. İkinci basamakta etkenin devam etmesiyle minede çözünme ve yumuşama artar ve mine mekanik etkilere duyarlı hale gelir ve tamamen ortadan kalkar. Çözünme dentine ulaştığında peritubuler dentin ile intertubuler dentin sınırında ilk çözünme başlar ve hızla ilerler. Tübüllerdeki genişleme sonucunda dentin hassasiyeti artar ancak yavaş ilerleyen erozyonlarda dentin, sklerotik dentin oluşturarak kendini korumaya alabilir ve hassasiyet gözlenmez [33].

Kritik pH değeri diş minesi için yaklaşık olarak 5.5 olarak belirlenmiştir. PH değeri 5.5 den düşük çözeltinin uzun süreli teması ve tekrarlı olarak diş yüzeyine uygulanması erozyona neden olmaktadır. Diş aşınma tipleri içinde en sık görülen erozyonun yaygınlığı hızlı, çabuk ve ayaküstü beslenme kültürünün yaygınlaştığı, modern hayatın bir getirisi olarak değişen yaşam biçimine ve toplumun beslenme alışkanlığına göre giderek artmaktadır ve gelişmiş toplumlar için ortak bir sorun haline gelmektedir [4,28].

\subsection{Erozyon Etyolojisi}

Dental erozyonun etyolojisi multifaktöriyel olmakla birlikte dış kaynaklı ya da iç kaynaklı asidik etkenlerle oluştuğu genel kabul görmektedir [29].

\subsubsection{Dış Kaynaklı [Ekstrinsink] Faktörler}

Vücuda dışarıdan alınan asitler dışsal faktörleri oluşturur. Günümüzde, asidik içeceklerin tüketiminin artmasıyla birlikte erozyon oluşumu da artmaktadır. Asidik bir içeceğin eroziv potansiyelini içerdiği asitin tipi, içeceğin pH'ı, içeriğindeki kalsiyum-fosfat-florid konsantrasyonu, diş yüzeyine olan adhezyon kuvveti ve şelasyon özelliği belirlemektedir [31,34].

İçeceklerde kullanılan asit tipinin erozyon potansiyelini etkilediğini gösteren çalışmalar bulunmaktadır. Asit türleri içinde en çok erozyon oluşturabilen sitrik asittir. Günümüzde birçok hazır gıda ve içecek sitrik asit içermektedir [35].

Asitli içeceklerin tüketim zamanı, şekli, miktarı ve sıklığı erozyonun oluşumunu etkileyen diğer bir faktördür. Asitli içecek tüketiminin zamanı erozyon oluşumu açısından önemlidir. Tükürük akışı öğünlerde, çiğneme fonksiyonuna bağlı olarak artarken; egzersiz sonrası ve uykuda azalmaktadır. Tüketimin tükürük akışının azaldığı döngülerde yapılması erozyon oluşumu riskini arttıran bir faktördür. Yine içeceklerin tüketim şeklide önemli bir konudur. Bu içeceklerin ağızda temas süresini arttırarak, bekletilerek içilmesi yerine pipet kullanımı tavsiye edilmektedir [4].

Asidik etkenlere maruz kalmış diş yüzeylerine aşırı kuvvetle ve abraziv diş macunu ile yapılan fırçalamanın erozyon oluşumunu arttırdığı literatürde bildirilmiştir [29]. Buna karşın kalsiyum, fosfat ve florür iyonları içeren diş macunlarının mine erozyonunu azaltmada etkili olduğu bilinmektedir [4,36].

Erozyona karşı koruyucu faktörlerden kabul edilen tükürüğün eroziv ajanlar üzerine seyreltme, tamponlama, temizleme etkisi bulunmaktadır. Kazanılmış pelikıl diş fırçalama, kimyasal ve profilaktik uygulamalar sonrasında diş yüzeyinden uzaklaşan 
ve yeniden oluşan, bakteri içermeyen bir biyofilm tabakası olarak tanımlanmaktadır. Bu tabakanın bir difüzyon bariyeri olarak asitlerin diş yüzeyine doğrudan temasını engellediği, hidroksiapatit kristallerinin çözünmesini azalttığı ve erozyona karşı koruyucu rol üstlendiği bildirilmiştir [33].

Bireyin mesleğinin ve spor aktivitelerinin dental erozyon oluşumunda etkili olabileceği belirtilmektedir. Akü fabrikasında çalışan ve asidik sıvı, gazlara maruz kalan işçilerde; dentin hassasiyetinin, ağız kuruluğunun ve dental erozyonun tesbit edildiğini gösteren çalışmalar vardır $[33,36]$. Ayrıca şarap tadımı gurmelerinin katıldığı bir çalışmada, üst keser dişlerin labiyal yüzeyinde dental erozyon tesbit edilirken; çürük aktivitesinin düşük olduğu ve uyarılmış-uyarılmamış tükürük akış hızında belirgin azalma olduğu bildirilmiştir [36].

Günümüzde spordan sonra tüketilen elektrolit dengesini geri kazandıran eroziv potansiyeli yüksek spor içeceklerinin tüketimi artmaktadır. Bu grup içeceklerin yüksek oranda dental erozyona sebep olduğu bildirilmiştir [37]. Egzersiz sonrası vücuttaki sıvı kaybı ve tükürük akışındaki azalma sonucu tükürüğün koruyucu fonksiyonlarındaki azalmaya bağlı olarak dental erozyona hassasiyet artmaktadır [36,37].

Dental erozyona sebep olabilecek sağlıksız yaşam biçimleri arasında alkolizm ve uyuşturucu bağımlılığı gibi kötü alışkanlıklar sayılabilir. Uyuşturucu madde kullanımında vücutta dehidratasyon artar, ağız kuruluğu meydana gelir buna bağlı olarak da dental erozyon oluşabilmektedir [33,36].

Dişlerin ağız boşluğundaki pozisyonu ve yumuşak dokular ile ilişkilerinin dental erozyon oluşumun etkilediği belirtilmektedir Dişlerin ağız içinde tükürük bezlerinin kanal ağızlarına olan yakınlıklarına bağlı olarak temizlenme oranında farklılıklar olduğu bilinmektedir. Buna bağlı olarak üst kesici dişlerin labial yüzeylerinin erozyon hassasiyeti yüksek, alt kesici dişlerin lingual yüzeylerinin ise erozyon hassasiyetinin düşük olduğu bildirilmektedir [25,33].

İlaç kullanımına bağlı olarak gelişen dental erozyonun, hastaların uzun bir süre ağız yolu ile aldıkları asidik ilaçların direkt olarak dişlerle teması ve aynı zamanda ilaçların yan etkisine bağlı olarak kusma ve tükürük akış hızındaki azalmaya bağlı olarak oluştuğu bildirilmiştir [38].

\subsection{2. İç Kaynaklı [İntrinsink] Faktörler}

İntirinsink faktörler, vücut kaynaklı asitler. Mide içeriğinin ağız ortamına ulaşmasıyla, vücut kaynaklı asitler erozyona sebep olur [39].

Mide asidinin ortalama pH değeri 1-1.5' dır. Birçok organik ve psikosomatik hastalığın belirtisi olan kusma, mide içeriğinin ağızdan kuvvetli şekilde atılmasıdır [28]. Ağıza ulaşan mide asitleri yani gastrik asit sonucu dişlerde erozyon meydana gelebilir. Erozyon oluşması için dişlerle temas süresi ve sıklığı önemlidir.
Bir ya da iki yıl boyunca haftada birkaç kez gastrik asitin dişlerle temas etmesi durumunda erozyon oluşmaktadır [4,28].

Dental erozyon görülme riskinin, haftada 1 kusma görülen bireylerde 4 kat, kronik kusma görülen bireylerde ise 18 kata kadar arttığını bildirmişlerdir [40]. İçsel faktörlere bağlı oluşan erozyonlar sıklıkla üst çenede kesici dişlerin palatinal yüzeylerinde görülmektedir. Erozyon lezyonları minede ya da dentinde sınırlı olabildiği gibi pulpaya kadarda ulaşabilmektedir $[4,41]$.

Yeme bozuklukları, tıbbi herhangi bir etken bulunmaksızın beslenme davranışlarını ısrarla reddeden, fiziksel ve psikososyal bozuklukların eşlik ettiği davranış bozukluğu olarak tanımlanmaktadır. Yeme bozukluklarından anoreksiya nevroza kişinin kendini bilinçli olarak aç bırakma davranışına bağlı olarak gelişen aşırı kilo kaybıdır. Bulumiya nevroza ise aşırı yemek yememin ardından kişinin bilinçli olarak kasıtlı kusma ile besinleri vücuttan çıkarmasıdır. Anorektik hastaların vücut ağırlıkları normalden oldukça düşükken, bulimik hastaların vücut ağırlıkları normal seviyede kaldığı belirtilmektedir [42]. Bulumianın tedavisinde kullanılan psikoaktif ilaçlar tükürük akışını azaltır. Böylece dolaylı olarak erozyon riskini arttırır [4,40,41].

Hamilelik tek başına dental erozyon sebebi değildir ancak bu dönemde hormonlardaki değişime bağlı olarak beslenme alışkanlıklarının değişmesi ve kusmaların görülmesi nedeniyle dental erozyona neden olabilmektedir [43]

Dental erozyona neden olan içsel faktörler arasında klinikte en çok karşılaşılan ağız boşluğu ile mideyi birbirine bağlayan özefagusu kontrol eden kaslardaki yetersizlikten kaynaklanan gastroözofagal reflü [GÖRH] dür. Bu hastalarda öğürme ya da kusma olmaksızın mide içeriği özefagal sfinkteri aşarak ağız boşluğuna dolar [41]. Sıklıkla dişlerin palatinal ve lingual yüzeylerinde erozyon görülür. Şiddetli vakalarda alt dişlerin okluzal ve bukkal yüzeylerinde oluşabilmektedir [4].

Regürjitasyonda mide içeriğinin ağıza dolması olarak tanımlanırken; ruminasyon dental literatürde sık rastlanan bir olgu olmamakla birlikte, geviş getirerek çiğnemeyi tanımlamaktadır [39].

\section{Diş Aşınmalarının Klinik Görünümü}

Dişlerin servikal bölgesinde çürük içermeyen, erozyon, abfraksyon ve abrazyon sonucu oluşan diş sert doku kayıpları 'çürüksüz servikal lezyon' olarak tanımlanır [25]. Zafersoy ve ark.'ları çürüksüz servikal lezyonların \%4.55'inin erozyon ve abrazyon, \%2.02'sinin erozyon ve abfraksyon , \% 8.58'sini erozyon, abfraksyon ve abrazyon sonucu oluştuğunu bildirmiştir. Erozyon, abrazyon, abfraksyon ve atrizyon lezyonları tek başına oluşabildiği gibi tek diş üzerinde birlikte de gözlenebilir [9]. [Şekil 2] 


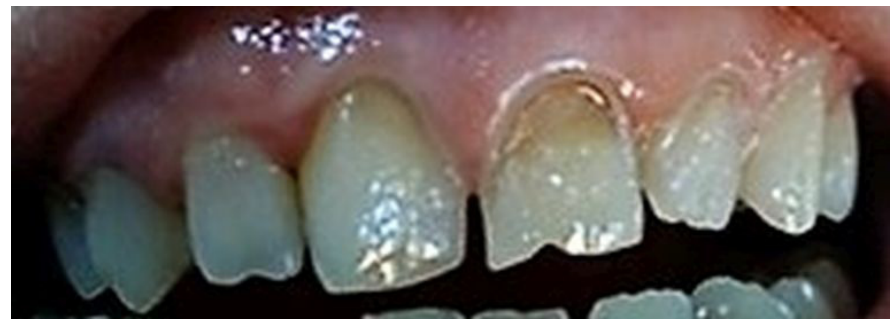

Resim 2: Erozyon, abfraksyon ve abrazyon defekti aynı diş üzerinde

Dişin dişe teması sonucunda oluşan atrizyon lezyonları yassı, parlak, lezyonlardır. Oklüzal yüzeyde oluştuğunda karşıt dişte de aynı lezyonun oluşması beklenir. [Şekil 3] Abrazyon lezyonlarının geniş̧liği derinliğinden fazladır. Oklüzal ve servikal alanda gözlenebilir [13,36].[Şekil 4]

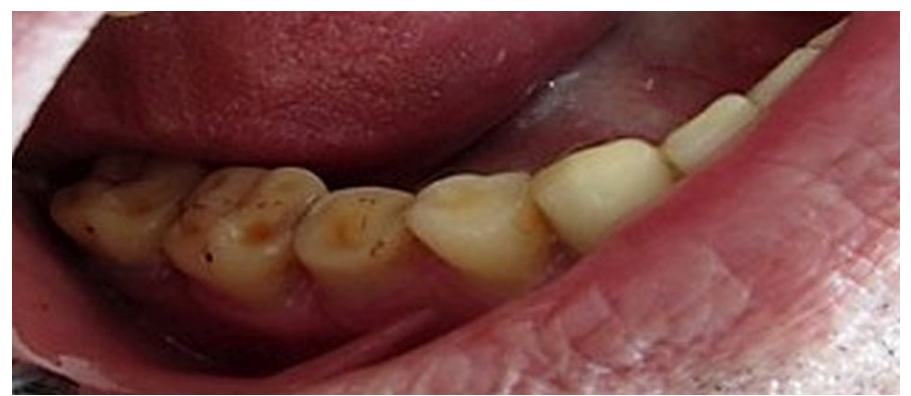

Resim 3: Atrizyon sonucu oluşan oklüzal diş aşınması

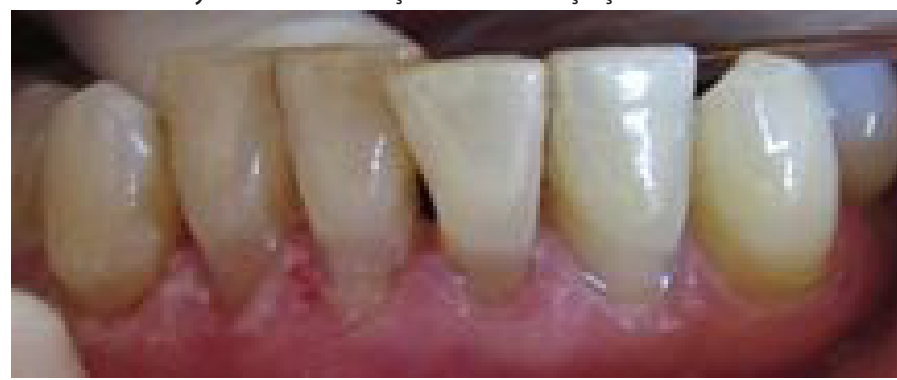

Resim 4: Abrazyon sonucu oluşan çürüksüz servikal lezyon

Abfraksiyon lezyonları kama şeklinde olup; mine-sement sınırının apikaline kadar uzanan, apikal sınırı düzensiz koronal sınırı keskin kenarlı, derinliği genişliğinden fazla olan lezyonlardır [36]. [Şekil 5]
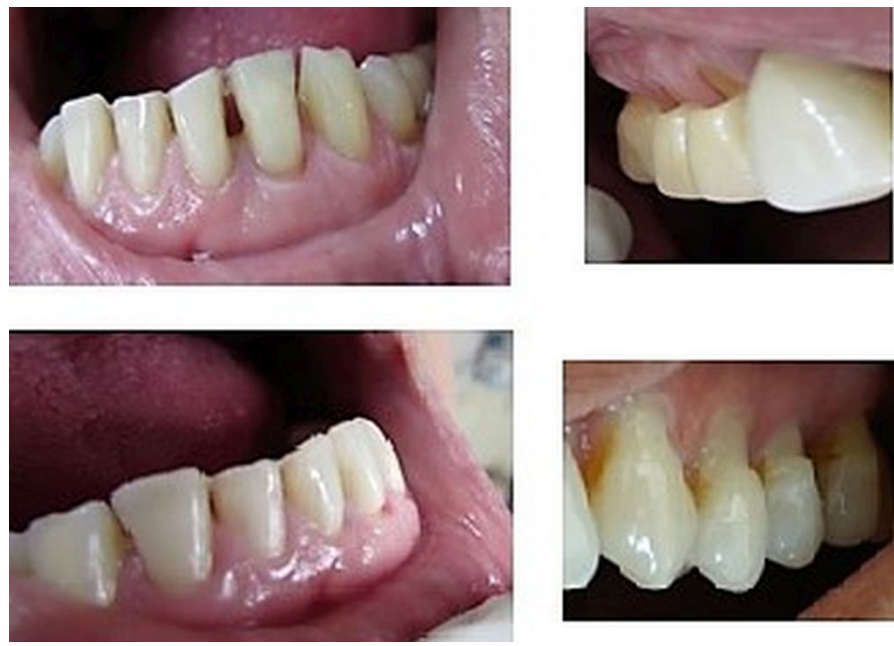

Resim 5 : Kama defekti
Dental erozyon vakalarında erken mine lezyonları klinik olarak renklenme, yumuşama ya da ağrıya neden olmaz. Başlangıç safasındaki lezyonlar 'Portakal Kabuğu' görünümündedir ve fark edilmesi zordur. Lezyon ilerledikçe mine tabakasından dentin tabakasına doğru derinleşir ve dentinin sarımtırak dokusu ortaya çıkar, oluşan kavite disk ya da 'U' şeklini alır. Lezyon ilerledikçe aşınma tüm faseti kaplayabilir ve derinliği artar. İlerlemiş vakalarda sklerotik dentin gözlenebileceği gibi pulpada açığa çıkmış olabilir [36]. [Şekil 6]

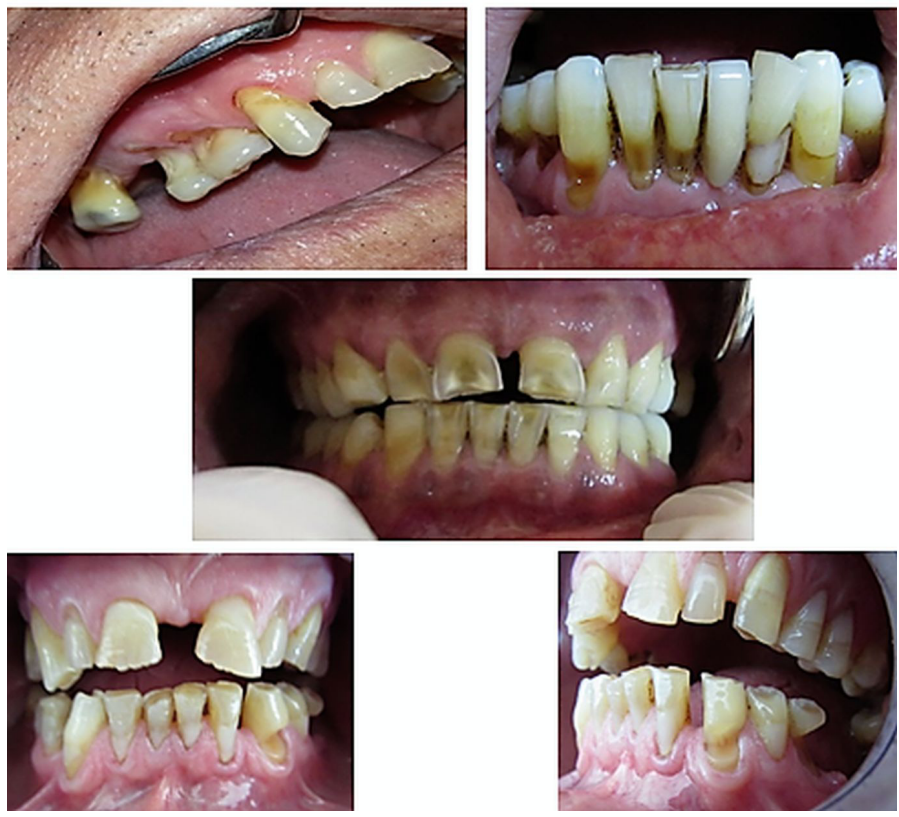

Resim 6: Şiddetli diş aşınmaları

Aktif erozyonda mine mat görünümlüdür. Erozyon yüzeyi abraze olduğunda yüzey parlak görünüm alır [33]. Kole bölgesindeki erozyon lezyonları dişin mine sement sınırının koronalinde oluşur. Lezyonun apikalinde sağlam mine dokusu kalabilir. Bu durum pelikılın bölgede difüzyon bariyeri oluşturması ya da pH'sı 7.5-8 olan diş eti oluğu sıvısının asitleri nötralize etmesiyle açıklanabilir [36].

Mine yüzeyi abrazyonda parlak, aktif erozyonda ise mat görüntü verir. Dental erozyon dişin tüm yüzeylerinde meydana gelebilmektedir. Çoğunlukla lezyonlar maksiler anterior dişlerin palatinali ve alt birinci molarların oklüzal yüzeylerinde gözlenir. Ağızdaki restorasyonların çevresindeki diş dokusuna göre şapka gibi yükselmiş görünmesi erozyonun klinik bulgularından biridir [28,32,40].

Erozyon leyonları servikal ve oklüzal-insizal alanda oluşabilmektedir. Mine-sement sınırı üzerinde, apikalde sağlam mine ile çevrili, genişliği derinliğini aşmayan lezyonlar şeklinde görünür [Şekil 7]. Erozyon lezyonları minedeki konkaviteler şeklinde de gözlenebilir. Bu konkaviteler "cupping" olarak isimlendirilir ve oklüzal alanda tüberküllerin tepelerinde lokalize olan oluşumlardır. Cuppinglerin özellikle posterior bölgede alt birinci molarlarda gözlendiği ve minede sınırlı kalabildiği gibi dentin dokusunuda içerebilmektedir [8]. 

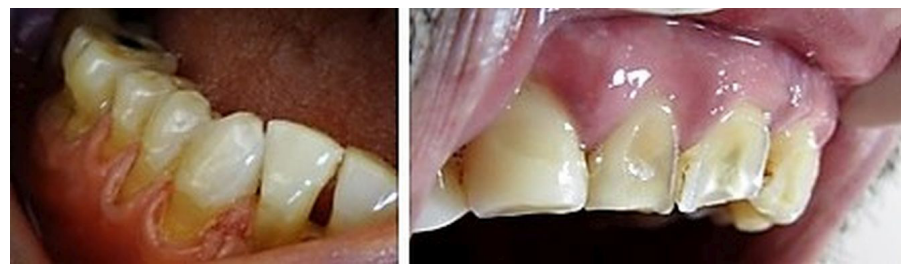

Resim 7: Erozyon sonucu oluşan çürüksüz servikal lezyonlar

\section{Sonuç}

Günümüzde yaşam süresinin uzaması ve dişlerin daha uzun süre ağızda kalmasına bağlı olarak diş çürüklerinden sonra ağız boşluğunun en sık görülen patolojileri diş aşınmalarıdır. Modern hayattan post modern hayata geçişte artan hayat temposu ve diyet alışkanlıklarının değişmesiyle, özellikle çocuk yaşlar denebilecek dönemde dahil olmak üzere, toplumlarda diş aşınması sonucu gelişen lezyonların görülme sıklığı ve şiddeti giderek artmakta ve toplumlar için ortak bir sorun haline gelmektedir. Buna paralel olarak estetik beklentinin karşılanması, oluşabilecek hassasiyetin giderilmesi ve yapısal bütünlüğün sağlanması amacıyla lezyonların tedavi gereksinimi ortaya çıkmaktadır.

\section{Maddi Destek ve Çıkar İlişkisi}

Çalışmayı maddi olarak destekleyen kişi/kuruluş yoktur ve yazarların çıkara dayalı bir ilişkisi yoktur.

\section{Kaynaklar}

1. Kitchin PC. The prevalence of tooth root exposure, and the relation of the extent of such exposure to the degree of abrasion in different age classes. J Dent Res 1941; 20: 565-81.

2. Lussi A, Schaffner M, Hotz $P$ et al. Dental erosion in a population of Swiss adults. Community Dent Oral Epidemiol 1991; 19: 286-90.

3. Hattab FN, Yassin OM. Etiology and diagnosis of tooth wear: a literature review and presentation of selected cases. Int J Prosthodont 2000; 13: 101-07.

4. Bor J, Anic I, Urek MM et al. The prevalence of non-carious cervical lesions in permanent dentition. J Oral Rehabil 2004; 31: 117-23.

5. Van SA, Rodriguez JM, Kreulen $\mathrm{CM}$ et al. Prevalence of tooth wear in adults. Int J Prosthodont 2009; 22: 35-42.

6. Eligüzeloğlu E, Üçtaşı $M B$, Ömürlü $H$, Ateşağaoğlu A ve ark. Gazi Üniversitesi Diş Hekimliği Fakültesi Tedavi Bölümüne Başvuran Bireylerde Çürüksüz Servikal Lezyon Görülme Sıklığı. Türkiye Klinikleri J Dental Sci 2008; 14: 80-4.

7. Kan S, Wenhui W, Xiaozhe W. et all. Tooth wear: a cross-sectional investigation of the prevalence and risk factors in Beijing, China, BDJ 2017;3:12-16.

8. Khan F, Young WG, Law V et al. Cupped lesions of early onset dental erosion in young southeast Queensland adults. Aust Dent J 2001; 46: 100-07.
9. Zafersoy Z, Kayaoğlu G, Can H ve ark. Çürük İçeren ve Çürük İçermeyen Servikal Lezyonların Etiyolojilerinin Klinik Olarak Değerlendirilmesi. Turkiye Klinikleri Journal of Dental Sciences 2002; 8: 86-91.

10. Ercan E, Kaya A. Dental erozyon: derleme. İstanbul Üni Diş Hek Fak Derg 2013; 47: 73-82.

11. Smith BGN, Knight JKM. Index for measuring the wear of teeth. Sr. Dent J 1984; 156: 435-36.

12. Imfeld T. Dental erosion. Definitions, classification and links. Eur J Oral Sci 1996; 104: 151-55.

13. Kopycka KDT, Meyerowitz C, Litaker MS et al. Management of Dentin Hypersensitivity by National Dental Practice-Based Research Network practitioners: results from a questionnaire administered prior to initiation of a clinical study on this topic. BMC Oral Health 2017; 13: 17-41.

14. Bishop $K$, Kelleher M, Briggs $P$ et al. Wear now? An update on the etiology of tooth wear. Quintessence Int 1997; 28: 305-13.

15. Terry DA, Mcguire MK, Mclaren E et al. Perioesthetic approach to the diagnosis and treatment of carious and noncarious cervical lesions: Part I. J Esthet Restor Dent 2003; 15: 217-32.

16. Silva $A G$, Martins $C C$, Zina $L G$ et al. The association between occlusal factors and noncarious cervical lesions: a systematic review. J Dent 2013; 41: 9-16.

17. Dülgergil Ç, Demirel G, Göçebe B ve ark. Kahramanmaraş Ili Mülteci Kampındaki Suriyeli Çocuklarda Çürük Görülme Sıklığının Değerlendirilmesi. Türkiye Klinikleri. Dishekimligi Bilimleri Dergisi 2017; 23: 1-8.

18. Grippo JO. Abfractions: A new classification of hard tissue lesions of teeth. J Esthet Dent 1991; 3: 14-9.

19. Litonjua LA, Andreana S, Bush PJ et al. Noncarious cervical lesions and abfractions: A re-evalution. J Am Dent Assoc 2003; 134: 845-50.

20. Grippo JO. Tooth flexure. J Am Dent Assoc 1991; 122: 13.

21. Lee $\mathrm{HE}$, Lin $\mathrm{CL}$, Wang $\mathrm{CH}$ et al. Stresses at the cervical lesion of maxillary premolar - a finite element investigation. J Dent 2002; 30: 283-90.

22. Pintado MR, Delong R, Ko CC et al. Correlation of noncarious cervical lesion size and occlusal wear in a single adult over a 14year time span. J Prosthet Dent 2000; 84: 436-43.

23. Nascimento MM, Dilbone DA, Pereira PN et al. Abfraction lesions: etiology, diagnosis, and treatment options. Clin Cosmet Investig Dent 2016; 8: 79-87.

24. Grippo JO, Simring M, Coleman TA. Abfraction, abrasion, biocorrosion, and the enigma of noncarious cervical lesions: a 20-year perspective. J Esthet Restor Dent 2012; 24: 10-23. 
25. Gargi SS, Sachin CS, Abfraction: A review. Journal of Oral and Maxillofacial Pathology 2013; 17: 222-27.

26. Levitch LC, Bader JD, Shugars DA et al. Non-carious cervical lesions. J Dent 1994; 22: 195-207.

27. Leinfelder KF. Restoration of abfracted lesions. Compend Contin Educ Dent 1994; 15: 1396-1400.

28. Atilla E, Eden E. Dental erozyon: etiyoloji, tanı ve tedavi yaklaşımı Ege Üni Diş Hek Fak Derg 2011; 33: 56-63.

29. -Lussi A, Jaeggi T, Zero D. The role of diet in the etiology of dental erosion. Caries Res 2004; 38: 34-44.

30. Kreulen CM, Van't SA, Rodriguez JM et al. Systematic review of the prevalence of tooth wear in children and adolescents. Caries Res 2010; 44: 151-59.

31. Ganss C, Klimek J, Giese K. Dental erosion in children and adolescents - a crosssectional and longitudinal investigation using study models. Community Dent Oral Epidemiol 2001; 29: 264-71.

32. El Aidi H, Bronkhorst EM, Huysmans MC et al. Dynamics of tooth erosion in adolescents: a 3-year longitudinal study. J Dent 2010 38: 131-37.

33. Lussi A. Dental erosion from diagnosis to therapy. Monogr Oral Sci 2006; 20: 44-65.

34. Attin T, Meyer K, Hellwig E et al. Effect of mineral supplements to citric acid on enamel erosion. Arch Oral Biol 2003; 48: 753-59.
35. Hannig C, Hamkens A, Becker K et al. Erosive effects of different acids on bovine enamel: release of calcium and phosphate in vitro. Arch Oral Biol 2005; 50: 541-52.

36. Wang $X$, Lussi A. Assessment and management of dental erosion. Dent Clin North Am 2010; 54: 565-78.

37. Hooper SM, Hughes JA, Newcombe RG et al. A methodology for testing the erosive potential of sports drinks. J Dent 2005; 33: 343-48.

38. Zero DT. Etiology of dental erosion--extrinsic factors. Eur J Oral Sci 1996; 104: 162-77.

39. Scheutzel P. Etiology of dental erosion- Intrinsic factors. Eur J Oral Sci 1996; 104: 178-90.

40. Jarvinen VK, Rytomaa II, Heınonen OP. Risk factors in dental erosion. J Dent Res 1991; 70: 942-47.

41. Moazzez R, Bartlett D, Anggiansah A.Dental erosion, gastrooesophageal reflux disease and saliva: how are they related. J Dent 2004; 32: 489-94.

42. Mcloughlin IJ, Hassanyeh F. Pica in a patient with anorexia nervosa. Br J Psychiatry 1990; 156: 568-70.

43. Fairburn CG, Stein A, Jones R. Eating habits and eating disorders during pregnancy. Psychosom Med 1992; 54: 665-72. 